S. Kovalevskyy, DSc, Prof., O. Kovalevska, $\mathrm{PhD}$, Assoc. Prof., A. Postavnichyi

\title{
DIAGNOSTICS OF MECHANICAL ENGINEERING PRODUCTS ON SEVERAL GROUNDS
}

С.В. Ковалевський, О.С. Ковалевська, А.С. Поставничий. Діагностика виробів машинобудування за кількома ознаками. У статті було розглянуто методи неруйнівного контролю, що засновані на різних фізичних законах і явищах. Розглянуто можливість створення нового актуального інструменту для отримання широкого спектру даних виробів машинобудування таких, як форма, розміри та розташування у просторі. Запропоновано використовувати звукову діагностику з застосуванням високочастотного широкосмугового сигналу для зняття частотних характеристик об’єкту. Метою дослідження є розробка методики безконтактного виміру виробів машинобудування за кількома ознаками. За допомогою віброакустичної діагностики та використанням методу контроля за кількісною ознакою було зроблено розподілення всього об'єму виробів 100 шт. на дві партії : основну и контрольну, знято кількісні параметри кожної одиниці виробу. За допомогою генератора частот подавався сигнал від 0 до 20000 Гц. Частотна характеристика кожного зразка фіксувалася у програмі Spectrum Analiyser. Оцінка відхилення розмірів виробу та його частотного спектру проведено у програмному забезпеченні NeuroPro 0.25. Створена нейронна мережа дозволяє в режимі реального часу прогнозувати значення декількох кількісних ознак незалежно від їх природи. Отримана працююча моделі збору статистичних даних для ефективної роботи нейронної мережі. Розроблена методика дозволяе виявляти конфігурацію виробів на основі непрямих вимірювань, через частотний спектр. Дану методику можливо використовувати для діагностики деталей за геометричними ознаками, фізичними властивостями, дефектами. Для цього необхідно збільшення вхідних даних для навчання нейронної мережі. При достатній виборці деталей з різними дефектами нейрона мережа за акустично частотними характеристиками зможе поділяти деталі на групи гідних і негідних за різними ознаками.

Ключові слова: неруйнівний контроль, нейронна мережа, діагностика, частотний спектр

S. Kovalevskyy, O. Kovalevska, A. Postavnichyi. Diagnostics of mechanical engineering products on several grounds. The article considers methods of non-destructive testing based on various physical laws and phenomena. The possibility of creating a new topical tool for obtaining a wide range of data of mechanical engineering products such as shape, size and location in space is considered. It is proposed to use sound diagnostics using a high-frequency broadband signal to capture the frequency characteristics of the object. The purpose of the study is to develop a method of non-contact measurement of mechanical engineering products on several grounds. With the help of vibroacoustic diagnostics and the method of quantitative control, the distribution of the entire volume of products was 100 pieces. on two parties: the main and control, quantitative parameters of each unit of a product are removed. A signal from 0 to $20,000 \mathrm{~Hz}$ was applied by means of a frequency generator. The frequency response of each sample was recorded in the Spectrum Analiyser program. Estimation of the deviation of the product size and its frequency spectrum was performed in the NeuroPro 0.25 software. The created neural network allows is predicted in real time values of several quantitative signs irrespective of their nature. A working model for collecting statistical data for the efficient operation of the neural network is obtained. The developed technique allows detecting the configuration of products on the basis of indirect measurements through the frequency spectrum. This technique can be used to diagnose parts by geometric features, physical properties, defects. This requires an increase in input data for neural network training. With a sufficient selection of parts with different defects of the neural network on the acoustic frequency characteristics will be able to divide the parts into groups of worthy and unworthy on various grounds.

Keywords: non-destructive testing, neural network, diagnostics, frequency spectrum

\section{Introduction}

To ensure the competitiveness of products, it is necessary to ensure its quality and reliability at optimal costs. Excessive costs for additional testing, technological, inspection and control operations increase the cost of products in production and increase the price, reducing the competitiveness of products on the market. That is why in modern conditions the question of choosing the optimal control strategy to improve the quality and reliability of products, while optimizing costs.

When choosing the optimal control strategy, it is necessary to solve the problem of reliable diagnosis and localization of the maximum number of potential defects at minimum cost.

Analysis of recent research and publications

There are two main types of defects [1]:

1. Explicit defects are defects for the detection of which in the regulatory documentation required for this type of control, the relevant rules, methods and tools. They are usually determined by a visual method - by inspecting the product and establishing the location, number and size of defects. 
2. Hidden defects are not detected by conventional methods. In metal products - these are internal cavities: sinks, cracks; in wood - knottiness and rot.

A significant defect significantly affects the intended use of the product and) its durability, but is not critical. For example, the formation of soot on the spark plug of a car's gasoline engine is a significant defect, as it indicates a malfunction of the engine and causes a decrease in its life [2, 3].

The purpose of the tasks of acoustic diagnostics of this class is to determine with the help of vibration or noise signals in which of several possible states is the object under study or which of several possible objects belongs to this acoustic signal.

We also note the system of acoustic diagnostics, designed for the selection and analysis of a series of sequential pulses (measured amplitudes, duration, and times of pulses), due to the collision of parts of a number of machines and mechanisms. The main principle of diagnostics of engineering structures and structures is to passively collect information from many sound (and ultrasonic) sensors, its localization and processing to further determine the area and degree of wear of the structure [4].

Acoustic emission (AE) is a consequence of the movement of the environment, which allows you to use it to diagnose processes and materials. For example, quantitative $\mathrm{AE}$ is a criterion of material integrity, which is determined by the sound radiation of the material during its control loading. The effect of acoustic emission can be used to detect the formation of internal defects at the initial stage of destruction of the structure. It can also be used to determine the degree of seismic hazard of geological rocks, and the emission can be caused artificially [5, 6].

Vibroacoustic treatment is a traditional acoustic treatment, but researchers are losing the ability to perform acoustic diagnostics not only on one but also on many frequencies.

This diagnostic technique has its own problems: it is a problem of contact of the investigated surface with the measuring device to improve the contact using various lubricating conductors, but it does not give the desired effect. Therefore, only a large number of parts can randomize the measurement error of the parts $[7,8]$.

Quantitative control is implemented by measuring the values of the quality attribute of the products included in the sample and testing hypotheses about the parameters of the distribution of the quality attribute in the batch (in the general set of products), which guarantee conditions under which the level of defects in the batch does not exceed the specified value $[9,10]$.

When controlling the quantitative feature, the controller must perform the following operations:

1. Using the means of measurements to record the value of the controlled parameter;

2. Find the sample arithmetic mean;

3. Evaluate its deviation Q from the nominal value or from the two values of the specified constraints (upper or lower);

4. Compare the obtained values with the pre-established control standards and based on the results of this comparison make decisions on the controlled batch of products (accepts or reject it).

When controlling a quantitative feature, the measurement results themselves are used directly to test the corresponding hypothesis by calculating some statistics (functions of random measurement results) and comparing them with the allowable values [11, 12, 13].

Thus, the advantage of quantitative control is that it is more informative and therefore requires a smaller sample size. However, such control is more expensive, because it requires such technical means that allow obtaining fairly accurate actual values of the controlled parameter. In addition, for statistical regulation in the control of quantitative characteristics required (sometimes complex) calculations associated with the definition of statistical characteristics.

The purpose of the study is to develop a method of non-contact measurement of mechanical engineering products on several grounds.

\section{Presentation of the main material}

Based on the analysis of the work performed by the department, the assumption is made about the need to create a universal tool through which it is possible to obtain a wide range of data on the object, namely: size, shape, location in space, but without overloading the technological system with many sensors and others devices for learning data from the tool. For this purpose, the possibilities of vibroacoustic processing and sound diagnostics with software for converting analog signal to digital using an ADC and its analogue in the sound card of a PC were used. The principle of operation is that a high-frequency broadband signal is applied, the frequency signals of the system are separated and 
the signal of the object itself is obtained, with subsequent separation of the main from secondary parameters of the object required to determine its shape, location or properties (Fig. 1).

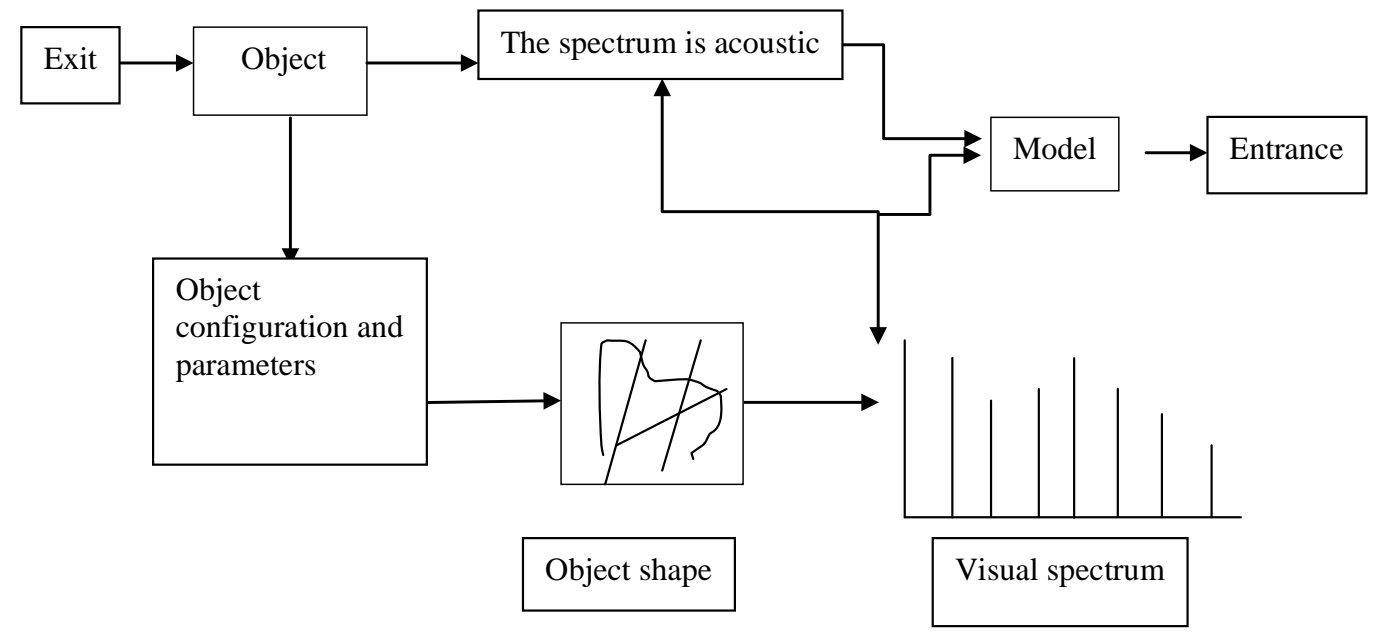

Fig. 1. Scheme of creating a training model

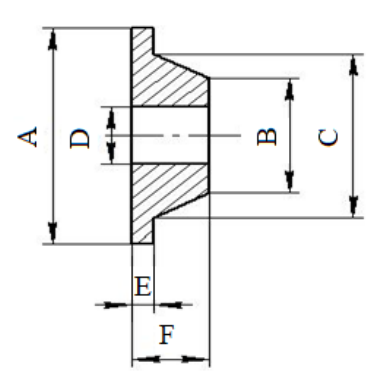

Fig. 2. Part of the washer type

100 samples were prepared for the experiment. As details the detail of type of a washer which has six geometrical parameters which are resulted in Fig. 2 was taken.

In order to identify the size of the samples, it is necessary to randomly divide the batch into two parts. With the help of a caliper, the geometrical indicators of the washer-type part were taken, and a table in the Microsoft Excel software product was compiled (Fig. 3).

Fig. 4 shows a diagram of the experimental setup. Based on this scheme, special equipment was used, which is connected in the following sequence. A generator is connected to the PC through which the frequency spectrum passed and entered the installation, so that the signal was transmitted to the resonator, which in turn passed the signal through the sample to the receiver.

A piezo element was used for the receiver and the resonator. The signal coming to the fre-

\begin{tabular}{|r|r|r|r|r|r|}
\hline \multicolumn{1}{|c|}{ B } & \multicolumn{3}{|c|}{ D } \\
\hline 48,33 & 30,35 & 16,27 & 7,70 & 1,73 & 8,97 \\
\hline 46,95 & 30,78 & 15,63 & 8,08 & 2,51 & 10,04 \\
\hline 47,90 & 28,90 & 14,80 & 7,91 & 1,90 & 9,41 \\
\hline 47,91 & 27,48 & 14,69 & 7,66 & 1,96 & 8,50 \\
\hline 46,92 & 30,37 & 15,44 & 7,70 & 2,08 & 9,55 \\
\hline 46,90 & 29,21 & 14,75 & 7,94 & 2,39 & 10,01 \\
\hline 47,84 & 31,66 & 16,24 & 8,44 & 1,73 & 9,45 \\
\hline 46,95 & 30,59 & 15,81 & 7,94 & 2,39 & 10,01 \\
\hline 48,63 & 29,59 & 13,70 & 8,13 & 2,17 & 9,97 \\
\hline 47,89 & 29,41 & 14,73 & 7,83 & 1,90 & 9,81 \\
\hline 48,34 & 31,57 & 15,43 & 7,68 & 2,81 & 11,17 \\
\hline 48,00 & 28,89 & 16,09 & 7,94 & 2,30 & 8,91 \\
\hline 46,79 & 30,72 & 16,06 & 8,11 & 2,48 & 10,06 \\
\hline 48,52 & 28,26 & 14,47 & 7,95 & 2,03 & 9,53 \\
\hline 47,02 & 29,50 & 15,65 & 18,05 & 2,51 & 9,75 \\
\hline 48,40 & 32,07 & 16,43 & 8,00 & 1,82 & 10,11 \\
\hline 47,51 & 29,30 & 15,55 & 7,89 & 1,97 & 9,12 \\
\hline 48,69 & 27,72 & 17,15 & 8,15 & 2,20 & 8,50 \\
\hline 48,31 & 28,84 & 15,93 & 8,10 & 2,06 & 9,22 \\
\hline 47,81 & 31,01 & 16,45 & 7,60 & 1,61 & 9,49 \\
\hline 46,71 & 32,80 & 15,51 & 8,00 & 3,05 & 11,60 \\
\hline 47,85 & 29,78 & 15,70 & 7,96 & 1,91 & 8,95 \\
\hline 47,38 & 31,20 & 15,60 & 8,02 & 1,69 & 9,22 \\
\hline 47,84 & 32,33 & 17,83 & 8,00 & 1,81 & 8,82 \\
\hline 47,74 & 30,40 & 17,35 & 8,21 & 1,59 & 9,43 \\
\hline 46,92 & 31,18 & 15,42 & 7,90 & 2,38 & 10,06 \\
\hline 47,43 & 29,85 & 14,97 & 8,14 & 1,54 & 8,24 \\
\hline 46,90 & 31,75 & 15,64 & 8,09 & 2,29 & 10,30 \\
\hline 48,48 & 30,41 & 17,19 & 8,02 & 2,34 & 9,07 \\
\hline 47,36 & 30,14 & 16,22 & 8,07 & 1,99 & 8,67 \\
\hline 46,88 & 31,00 & 16,20 & 7,98 & 2,31 & 9,97 \\
\hline 47,76 & 28,84 & 15,92 & 7,96 & 2,25 & 9,35 \\
\hline 46,89 & 28,91 & 14,42 & 8,03 & 1,74 & 9,38 \\
\hline 48,16 & 29,91 & 13,65 & 7,96 & 1,53 & 9,44 \\
\hline & & & & & \\
\hline
\end{tabular}

Fig. 3. Input about washer part size 
quency receiver came to the PC, where the Spectrum Analiyser program displayed the frequency spectrum. Thus, information on the frequency response of each sample was obtained [14].

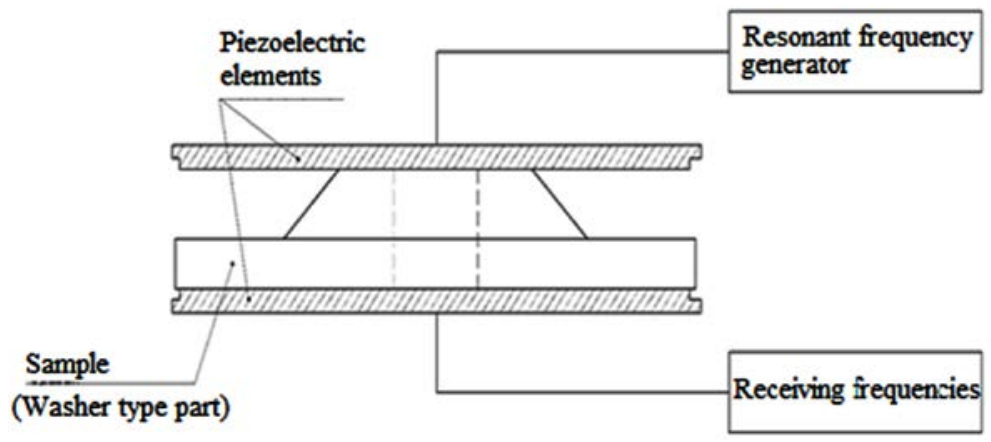

Fig. 4. Scheme of experimental installation

Vibroacoustic treatment is a traditional acoustic treatment, but researchers are losing the ability to perform acoustic diagnostics not only on one but also on many frequencies. Sound diagnostics: the maximum information is born from white noise, as the effect of sound decomposition is manifested, which allows to select elements of the conductor configuration. To recognize the conductor, a set of statistics of frequency spectra of elements of a complex object is collected.

Thus, the analysis of the properties of the object and its shape is performed, and the frequency spectrum and the configuration in the form of a graph of the spectrum distribution are obtained.

Next, you need to translate the resulting acoustic spectrum into a visual version for further processing and obtaining the necessary features and properties in order to create a model. The data that were removed from the installation were transferred to a Microsoft Excel spreadsheet, and then a table of precedents was created for further modeling (Fig. 5).

\begin{tabular}{|c|c|c|c|c|c|c|c|c|c|c|c|c|c|c|c|}
\hline A) & SL & SM & SN & so & 50 & sa & SR & S5 & ST & SU & SV & $5 W$ & $5 x$ & SY & $\mathbf{8}$ \\
\hline 1 & 21705,5 & 21748,5 & 21791,6 & 21834,7 & 2187,7 & 21920,8 & 21963,9 & 22006,9 & 22050 & & B & C & 0 & E & E \\
\hline 2 & $.99,4$ & $.99,28$ & $.99,7$ & $-100,62$ & $.100,14$ & $-100,83$ & $\cdot 100, n$ & $-100,58$ & $-107,03$ & 48,33 & 30,35 & 16,27 & 7,70 & 1.73 & 8.97 \\
\hline 3 & $-100,98$ & $-201,07$ & $\cdot 200,12$ & $-100,4 s$ & $\cdot n, 7$ & $-200,25$ & $-201,15$ & $-101,48$ & -204.25 & 46,25 & 30,7 & 25,61 & 8.09 & 2.53 & 10,0 \\
\hline 4 & $-100,14$ & $-100,03$ & $-100,39$ & $-100,79$ & $-101,36$ & $-100,74$ & $-100,67$ & $-100,86$ & $-107,75$ & 47,90 & 28,90 & 14.80 & 7.91 & 1.90 & 9.41 \\
\hline 5 & $\cdot 99,97$ & $-100,25$ & $\cdot 100,20$ & $-100,25$ & $-100,87$ & $-101,22$ & $.100,49$ & $\cdot 100,27$ & $-107,55$ & 47,21 & 27,45 & 24,69 & 7,60 & 1.96 & 8.50 \\
\hline 6 & $\cdot 100,81$ & $-201,11$ & $-100,44$ & $\cdot 100,73$ & $-100,95$ & $-100,32$ & $-100,36$ & $-100,08$ & $-106,60[$ & 46,92 & 30,37 & 15,44 & 7,70 & 2.00 & $9,5 \mathrm{~s}$ \\
\hline 7 & $-100,52$ & 99 & $.92,94$ & $.99,65$ & $.99,83$ & $.100,63$ & $-100,95$ & $\cdot 100,58$ & $\cdot 107, n$ & 46,90 & 29.21 & 24,75 & 7,94 & 2,39 & 10.01 \\
\hline 8 & $-101,65$ & $-100,48$ & $-100,00$ & $-100,29$ & $\cdot 99,59$ & $\cdot 99,76$ & $-100,12$ & $-100,72$ & $\cdot 107,55$ & 47,84 & 31.66 & 16,24 & 8.44 & 2,73 & 9,45 \\
\hline 9 & $-100,69$ & $-100,6$ & $\cdot 100,35$ & $-101,27$ & $-100,74$ & $-100,69$ & $-100,4$ & $-100,22$ & $-106,82$ & 46,95 & 30,52 & 15.81 & 7,94 & 2,39 & 10.02 \\
\hline 10 & $-100,02$ & $-200,55$ & $-202,25$ & $-200,6$ & $-200,25$ & $-200,27$ & $-100,01$ & $-100,44$ & $-207,85$ & 49,63 & 29.52 & 11,20 & 8.13 & 2,17 & 2.97 \\
\hline 11 & 99,79 & $.99,89$ & $\cdot 99,91$ & 99,98 & $-100,76$ & $-100,41$ & $\cdot 99,93$ & $\cdot 99,73$ & $-107,8$ & 47,89 & 29.41 & 24,73 & 7,83 & 1.90 & 2.81 \\
\hline 12 & $\cdot 9,72$ & $-200,03$ & $-200,1$ & $\cdot 2,78$ & $\cdot 96,37$ & $-200,5 s$ & $-100,69$ & $-100,51$ & $-207,04$ & 48,24 & 31.57 & 25.43 & 7,6 & 2.81 & 21213 \\
\hline 13 & $\cdot 100,9$ & $\cdot 100,61$ & $-100,57$ & $\cdot 100,72$ & $\cdot 99,85$ & $\cdot 99,95$ & $\cdot 99,62$ & $-100,45$ & $\cdot 107,63$ & 48,00 & 28,89 & 16,09 & 7,94 & 2,30 & 8.91 \\
\hline 14 & $.99,59$ & $-100,3$ & $\cdot .100,18$ & $\cdot 100,73$ & $-100,66$ & $.201,15$ & $.99,92$ & $.99,65$ & $-106,95$ & 46,79 & 30,72 & 16.06 & 8,11 & 2.48 & 10.06 \\
\hline 15 & $-98,8$ & $-200,53$ & $-101,52$ & $\cdot 101,2$ & $-100,69$ & $-100,4$ & $-100,25$ & $-100,72$ & $\cdot 107,7$ & 48,52 & 28.26 & 34,47 & 7,95 & 2.03 & 9.53 \\
\hline 16 & $-100,63$ & $.100,53$ & $-101,05$ & $-100,61$ & $-100,7$ & $-100,61$ & $.99,52$ & $.99,95$ & $\cdot 107,85$ & 47.02 & 29.50 & 15.65 & 18.05 & 2.51 & 9,75 \\
\hline 17 & $-97,81$ & $-95,43$ & $-25,48$ & $\cdot 94,75$ & $-200,19$ & $-200,54$ & $-100,72$ & $-100,46$ & $-107,19$ & 49,40 & 32,07 & 16,4] & $8 . \infty$ & 2,02 & 10,11 \\
\hline 18 & $-100,11$ & $-100,76$ & $-100,74$ & $-100,83$ & $-100,24$ & $-100,21$ & $-100,43$ & 99,65 & $-106,29[$ & 47,51 & 29,30 & 15.55 & 7.89 & 1.97 & 9.12 \\
\hline
\end{tabular}

Fig. 5. Table of precedents

Based on the precedent table, a neural network was created with the help of software, namely NeuroPro 0.25 , to process the frequency spectrum and detect and filter out the required main parameters of the object.

Based on the trained neural network, the test sample was analyzed in comparison with the processed data in NeuroPro and a lack in the batch of Fig. 6 was revealed.

Based on the trained model, statistical information was collected for further use in the identified forms, properties and location of the processed object with different eigenvalues $[15,16]$. The experiment 
showed that the construction of a neural network of parts allows determining almost instantly the geometric dimensions of parts on the basis of acoustic - frequency characteristics with an accuracy of $0.03 \mathrm{~mm}$.

\begin{tabular}{|c|c|c|c|c|c|c|c|c|c|}
\hline$N^{*}$ & A & Прогноз сети & Ошибка & $B$ & Прогноз сети & Ошибка & c & Прогноз сети & Ошибка \\
\hline 33 & 48.4 & 48,44065 & $-0,04065476$ & 29.9 & 30.23416 & $-0,3341556$ & 15.5 & 14,71071 & 0.7892933 \\
\hline 34 & 48 & 47,79962 & 0,2003784 & 27.4 & 28.02312 & -0.6231209 & 13,4 & 14,00104 & -0.6010405 \\
\hline 35 & 48 & 47.5041 & 0.4958954 & 30.8 & 31.06613 & -0.2661297 & 16.8 & 16.07674 & 0.7232617 \\
\hline 36 & 46.6 & 46.11515 & 0.4848457 & 30.4 & 29.80076 & 0.5992378 & 10.1 & 10.78918 & -0.6891836 \\
\hline 37 & 47,9 & 48,43053 & $-0,5305306$ & 30 & 29,36971 & 0,6302948 & 11 & 11,87178 & $-0,8717775$ \\
\hline 38 & 48,2 & 47,55003 & 0,649974 & 31,4 & 32,0303 & $-0,6302963$ & 15,6 & 16,22936 & -0.6293567 \\
\hline 39 & 46.96 & 47.60071 & $-0,6407118$ & 30.88 & 30.7799 & 0.1001042 & 15.72 & 15,36464 & 0,3553636 \\
\hline 40 & 48,32 & 48.665 & $-0,3449971$ & 29.99 & 30.35273 & $-0,3627317$ & 14.25 & 1453494 & -0.2849436 \\
\hline 41 & 47.97 & 48.49156 & -0.521558 & 31.76 & 32.28649 & -0.5264876 & 17 & 16.98048 & 0.01951981 \\
\hline 42 & 48.61 & 48.91718 & -0.3071791 & 30.4 & 30.88914 & -0.489143 & 14.6 & 15.44905 & -0.849048 \\
\hline 43 & 48,92 & 48,25619 & 0,6638126 & 30,17 & 29,51523 & 0,6547717 & 15,98 & 15,20192 & 0,7780786 \\
\hline \multirow[t]{5}{*}{44} & 48,3 & 47,66975 & 0,6302536 & 31,12 & 31,63974 & $-0,5197381$ & 16,58 & 15,7285 & 0,8514968 \\
\hline & & Превильно: & $44(100 \%)$ & & Правильно: & $44(100 \%)$ & & Провильно: & $44(100 \%)$ \\
\hline & & Непровильно: & $0(0 \%)$ & & Непровипьно: & $0(0 \%)$ & & Непровильно: & $0(0 \%)$ \\
\hline & & Bcero: & 44 & & Bcero: & 44 & & Bcero: & 44 \\
\hline & & Ср.ошибке: & 0.4025835 & & Cр.ошибке: & 0.4577485 & & Cр.ошибке: & 0.5733256 \\
\hline
\end{tabular}

Fig. 6. Testing

The results of experimental research proved the possibility of contactless control of products on several quantitative grounds simultaneously. The number of controlled symptoms is not limited. To simultaneously control many sizes of products, it is enough to have a neural network model, consistent with the requirement of maximum dimensional accuracy. The neural network model may have excess capacity, which allows you to have different types of products and their control. The created neural network allows predicting in real time values of several quantitative signs irrespective of their nature; Reduction of neuron-like elements of the model allows increasing its speed, but reducing the accuracy of the forecast. The practical application of the model can be implemented on the basis of microprocessor technology and can represent an industrial model of a contactless control system of several sizes simultaneously.

\section{Conclusions}

The article considered the possibility of creating a new topical tool for obtaining a wide range of data (shape, properties, location in space) on the object of processing and obtaining a working model for collecting statistical data for further creation of a statistical database. This technique can be used to diagnose parts by geometric features, physical properties, defects. This requires an increase in input data for neural network training. With a sufficient sample of parts with different defects of the neural network on the acoustic frequency characteristics will be able to divide the parts into groups of worthy and unworthy on various grounds.

The developed technique allows carrying out diagnostics of objects, to reveal a configuration of products on the basis of indirect measurements, through a frequency spectrum which possess high dynamics and speed.

\section{Література}

1. Назолін А.Л. Оцінка можливості виявлення дефектів статора турбогенератора по спектру віброакустичнго сигналу. Заводская лаборатория. Диагностика материалов. 2017. Вип. 4. 314 с.

2. Basaran F. U., Kurban M. A New Approach for the Short-Term Load Forecasting with Autoregressive and Artificial Neural Network Models. International Journal of Computational Intelligence Research. 2007. № 3. P. 66-71. 
3. Коновалова І.О., Беркович Ю.А., Єрохін А.Н. Оптимізація світлодіодної системи освітлення вітамінами космічної теплиці. Авіакосмічна і екологічна медищина. 2016. Вип. 50, № 3. С. 17-22.

4. Кононюк А. Е. Обобщенная теория моделирования. Начала: Освіта України, 2012. 602 с.

5. Бигус Г.А., Даниев Ю.Ф., Быстрова Н.А. Диагностика технических устройств. М. : Изд-во МГТУ им. Н.Э. Баумана, 2014. 615 с.

6. Бобров В.Т., Самокрутов А.А., Шевалдыкин В.Г. Техническая диагностика и неразрушающий контроль Состояние и тенденции развития акустических (ультразвуковых) методов, средств и технологий неразрушающего контроля и технической диагностики. Территория NDT. 2018. № 2. С. 24-27.

7. Ермолов И.Н. Техническая диагностика и неразрушающий контроль. Достижения в теоретических вопросах ультразвуковой дефектоскопии, задачи и перспективы. Дефектоскопия. 2018. № 2. С. 13-48.

8. Терентьев В.Ф., Колмаков А.Г., Блинов В.М. Деформация и разрушение материалов. Деформаuия и разрушение материалов. 2007. № 6. С. 2-9.

9. Белолапотков Д.А., Добровинский И.Р., Медведик Ю.Т. Повышение точности активного контроля размеров деталей в процессе изготовления. Мир измерений М. РИА «Стандарты и качество». 2007. № 7. С. 43-46.

10. Леньков С.В., Федорова Н.В. Резонансный электромагнитный - акустический метод измерения вязкоупругих свойств аморфных ферро магнитных лент, подвергнутых низкотемпературному отжигу. Физика металлов и металловедение. 2014. № 115. С. 749-755.

11. Верещака А.С., Высоцкий В.В., Мокрицкий Б.Я. Технологические процессы повышения работоспособности металлорежущего инструмента. Комсомольск-на-Амуре : ФГБОУ ВПО «КнАГТУ», 2013. $208 \mathrm{c}$.

12. Самотугин С.С., Лещинский Л.К. Плазменное упрочнение инструментальных материалов. Донецк : Новый мир, 2002. 338 с.

13. Golesorkhtabar R. A. ElaStic: A tool for calculating second-order elastic constants from first principles. Computer Physics Communications. 2013. № 8. P. 1861-1873.

14. Kovalevska O. S., Kovalevskyy S. V. Application of acoustic analysis in control systems of robotic machine tools. Radio Electronics, Computer Science, Control. 2018. № 2(45). C. 51-59.

15. Kovalevskyy S.V., Kovalevska O.S., Turmanidze R.A. Acoustic diagnostics of lever mechanisms with subsequent processing of data on neural networks. New technologies, development and application. Springer International Publishing AG, part of Springer Nature. 2018. Vol. 42. P. 202-210.

16. Kovalevskyy S. V., Kovalevska O.S. Resource optimization with systemic design of robotized technological equipment. World Convention on Robots, Autonomous Vehicles and Deep Learning. 10-11 September 2018, Singapore. 2018. P. 50. DOI: 10.4172/2168-9695-C3-0216th.

\section{References}

1. Nazolin, A.L. (2017). Evaluation of the possibility of detecting defects of the stator of the turbogenerator on the spectrum of the vibroacoustic signal. Factory laboratory. Diagnostics of materials.

2. Basaran, F. U., \& Kurban, M. A. (2007). New Approach for the Short-Term Load Forecasting with Autoregressive and Artificial Neural Network Models. International Journal of Computational Intelligence Research, 3, 66-71.

3. Konovalova, I.O., Berkovich, Yu.A., \& Erohin, A.N. (2016). Optimization of the LED lighting system vitamins space greenhouse. Aviakosmicheskaja i jekologicheskaja medicina, 50, 3, 17-22

4. Kononyuk, A.E. (2012). Generalized modeling theory. Beginnings: Education of Ukraine.

5. Bigus, G.A., Daniev, Y.F., \& Bystrova, N.A. (2014). Diagnostics of technical devices. Moscow: MSTU im. N.E. Bauman.

6. Bobrov, V.T., Samokrutov, A.A., \& Shevaldykin, V.G. (2018). Technical diagnostics and nondestructive testing. The state and trends in the development of acoustic (ultrasonic) methods, tools and technologies of non-destructive testing and technical diagnostics. NDT territory, 2, 24-27.

7. Ermolov, I.N. (2018). Technical diagnostics and non-destructive testing. Advances in theoretical issues of ultrasonic flaw detection, tasks and prospects. Defectoscopy, 2, 13-48.

8. Terentyev, V.F., Kolmakov, A.G., \& Blinov, V.M. (2007). Deformation and destruction of materials. Deformation and destruction of materials, 6, 2-9.

9. Belolapotkov, D.A., Dobrovinsky, I.R., \& Medvedik, Yu.T. (2007). Improving the accuracy of active control of the size of parts in the manufacturing process. The world of measurements M. RIA Standards and quality, 7, 43-46. 
10. Lenkov, S.V., \& Fedorova, N.V. (2014). Resonant electromagnetic is an acoustic method for measuring the viscoelastic properties of amorphous ferro magnetic tapes subjected to low-temperature annealing. Physics of metals and metallurgy, 115, 749-755.

11. Vereshchaka, A.S., Vysotsky, V.V., \& Mokritsky, B. Ya. (2013). Technological processes of increase of working capacity of the metal-cutting tool. Komsomolsk-on-Amur: FGBOU VPO KnAGTU.

12. Samotugin, S.S., Leshchinsky, L.K. (2002). Plasma hardening of tool materials. Donetsk: New World.

13. Golesorkhtabar, R. A. (2013). ElaStic: A tool for calculating second-order elastic constants from first principles. Computer Physics Communications, 8, 1861-1873.

14. Kovalevska, O. S., \& Kovalevskyy, S. V. (2018). Application of acoustic analysis in control systems of robotic machine tools. Radio Electronics, Computer Science, Control, 2 (45), 51-59.

15. Kovalevskyy, S.V., Kovalevska, O.S., \& Turmanidze, R.A. (2018). Acoustic diagnostics of lever mechanisms with subsequent processing of data on neural networks. New technologies, development and application. Springer International Publishing AG, part of Springer Nature, 42, 202-210.

16. Kovalevskyy, S.V., \& Kovalevska, O.S. (2018). Resource optimization with systemic design of robotized technological equipment. World Convention on Robots, Autonomous Vehicles and Deep Learning. Singapore. DOI: 10.4172/2168-9695-C3-0216th.

Ковалевський Сергій Вадимович; Kovalevskyy Sergii, ORCID: https://orcid.org/0000-0002-4708-4091

Ковалевська Олена Сергіївна; Kovalevska Olena, ORCID: https://orcid.org/0000-0001-5884-0430

Поставничий Андрій Сергійович; Postavnychyi Andrii

Received November 01, 2020

Accepted December 17, 2020 